\title{
Penyuluhan Kesehatan tentang Faktor Penyebab Kekambuhan Pasien Skizofrenia
}

\author{
Dwi kartika Pebrianti \\ Progam Studi Ilmu Keperawatan STIKes Baiturrahim Jambi \\ Email :dwiekartika86@gmail.com
}

Submitted : 06/12/2020

Accepted: 16/106/2021

Published: 19/11/2021

\begin{abstract}
Schizophrenia is a disease that affects the brain and causes strange and disturbed thoughts, perceptions, emotions, movements and behaviors called schizophrenia. Globally, the recurrence rate in people with mental disorders reaches 50\% -92\% due to non-compliance in treatment or due to lack of support and vulnerable living conditions with increased stress. Clients diagnosed with schizophrenia are estimated to have a 50\% relapse in the first year, $70 \%$ in the second year after discharge from hospital, and a 100\% recurrence in the fifth year. Data on patient visits at the Outpatient Polyclinic of RSJD Jambi Province in 2016 amounted to 38,330 visits, of which 35,448 visits were repeat visits and the remaining 2882 were new visits. It is hoped that the results of health education activities for patients and their families will understand the concept of nursing problems that cause mental disorder patients to recur.
\end{abstract}

Keywords : family support, medication adherence,relapse, szikophrenia

\begin{abstract}
Abstrak
Skizofrenia merupakan suatu penyakit yang mempengaruhi otak dan menyebabkan timbulnya pikiran, persepsi, emosi, gerakan dan perilaku yang aneh dan terganggu disebut sebagai skizofrenia. Secara global angka kekambuhan pada penderita gangguan jiwa mencapai 50\%-92\% yang disebabkan karena ketidakpatuhan dalam berobat maupun karena kurangnya dukungan dan kondisi kehidupan yang rentan dengan meningkatnya stres. Klien dengan diagnosa skizofrenia diperkirakan akan kambuh 50\% pada tahun pertama, 70\% pada tahun kedua setelah pulang dari rumah sakit, kekambuhan $100 \%$ pada tahun kelima. Data kunjungan pasien di Poliklinik Rawat Jalan RSJD Provinsi Jambi tahun 2016 berjumlah 38.330 kunjungan, dari jumlah tersebut sebanyak 35.448 kunjungan merupakan kunjungan berulang dan sisa 2882 adalah kunjungan baru. Hasil dari kegiatan penyuluhan kesehatan pada pasien dan keluarga diharapkan keluarga memahami konsep tentang masalah keperawatan penyebab kekambuhan pasien gangguan jiwa.
\end{abstract}

Kata kunci : dukungan keluarga, kekambuhan, kepatuhan minum obat, szikofrenia,

\section{PENDAHULUAN}

Gangguan jiwa adalah kesulitan yang harus dihadapi oleh seseorang karena hubungannya dengan orang lain, kesulitan karena persepsinya tentang kehidupan dan sikapnya terhadap dirinya sendiri. Gangguan jiwa yang disebut juga dengan gangguan mental merupakan gangguan dalam cara berpikir (cognitive), kemauan (volition), emosi (affective), tindakan (psychomotor), istilah dalam PPDGJ gangguan jiwa atau gangguan mental yakni sindrom perubahan perilaku dan psikologis karena faktor stressor atau ketidakberdayaan dan beresiko mengganggu fungsi kehidupan keseharian individu (PPDGJ, 2013). Gangguan jiwa berat yang sering ditemukan dimasyarakat adalah skizofrenia. Skizofrenia adalah sekumpulan sindroma klinik yang ditandai dengan perubahan kognitif, emosi, persepsi dan aspek lain dari perilaku (Kaplan \& Saddock, 2007).

Skizofrenia merupakan gangguan psikotik yang ditandai dengan gangguan utama dalam pikiran, emosi dan prilaku yang terganggu, dimana berbagai pemikiran tidak saling berhubungan secara logis, persepsi dan perhatian yang keliru, afek 
yang datar atau tidak sesuai dengan berbagai gangguan aktivitas motorik yang bizarre (Kunter, 2009). Skizofrenia merupakan suatu penyakit yang mempengaruhi otak dan menyebabkan timbulnya pikiran, persepsi, emosi, gerakan dan perilaku yang aneh dan terganggu disebut sebagai skizofrenia (Videbeck, 2008).

Menurut data WHO (2016), terdapat sekitar 35 juta orang terkena depresi, 60 juta orang terkena bipolar, 21 juta terkena skizofrenia, serta 47,5 juta terkena demensia. Prevalensi pasien skizofrenia di Indonesia menurut Riskesdas (2013) adalah sekitar 1,7 per mil orang yang menderita gangguan jiwa dengan prevalensi provinsi tertinggi adalah D.I Yogyakarta dan D.I Aceh sebesar 2,7 \% dan terendah adalah Kalimantan Barat dengan prevalensi 0,7 \%. Untuk prevalensi gangguan jiwa berat di provinsi Jambi sebesar 0,9\%. Apabila penduduk Indonesia di asumsikan sekitar 200 juta jiwa, maka diperkirakan sekitar 2 juta jiwa penduduk menderita skizofrenia (Kemenkes RI, 2013).

Data yang dirilis oleh RS jiwa Daerah Provinsi Jambi berdasarkan Profil RSJD Provinsi Jambi tahun 2018 didapatkan bahwa diagnosis skizofrenia masih menduduki urutan teratas pada klien yang melakukan control ulang di instalasi rawat jalan. Berikut data jumlah penderita skizofrenia di rawat jalan.

Kronisitas gangguan skizofrenia merupakan salah satu faktor yang dipertimbangkan dalam penatalaksanaan, meskipun pengobatan farmakologik merupakan pilihan utama dalam penatalaksanaan. Hampir semua pasien skizofrenia kronis mengalami kekambuhan sehingga mengakibatkan defisit ketrampilan personal dan vokasional. Kekambuhan dapat disebabkan oleh ketidakpatuhan minum obat, gejala yang refrakter terhadap pengobatan, peristiwa kehidupan yang menimbulkan stres, kerentanan individu terhadap stres, ekspresi emosi keluarga yang tinggi, serta yang tidak kalah penting adalah dukungan keluarga dalam penatalaksanaan penyakit ini (Videbeck, 2008).

Secara global angka kekambuhan pada penderita gangguan jiwa mencapai $50 \%-92 \%$ yang disebabkan karena ketidakpatuhan dalam berobat maupun karena kurangnya dukungan dan kondisi kehidupan yang rentan dengan meningkatnya stres (Sheewangisaw, 2012). Klien dengan diagnosa skizofrenia diperkirakan akan kambuh 50\% pada tahun pertama, $70 \%$ pada tahun kedua setelah pulang dari rumah sakit, kekambuhan $100 \%$ pada tahun kelima.

Angka kekambuhan pasien gangguan jiwa di Provinsi Jambi pada tahun 2015 yang tercatat mencapai $81,3 \%$. Jumlah pasien rawat inap yang tercatat tahun 2015 berjumlah 1583 penderita dengan 1287 penderita merupakan pasien lama yang mengalami kekambuhan. Data kunjungan pasien di Poliklinik Rawat Jalan RSJD Provinsi Jambi tahun 2016 berjumlah 38.330 kunjungan, dari jumlah tersebut sebanyak 35.448 kunjungan merupakan kunjungan berulang dan sisa 2882 adalah kunjungan baru. Tahun 2016 jumlah kunjungan meningkat menjadi 40.152 kunjungan dengan jumlah kunjungan baru sebanyak 39.427 kunjungan merupakan kunjungan berulang. Tahun 2017 jumlah kunjungan mengalami peningkatan kembali menjadi 43.736 kunjungan dimana sebanyak 41.862 kunjungan merupakan kunjungan berulang. Tahun 2019 jumlah kekambuhan yang dihitung berdasarkan kunjungan pasien skizofrenia terhitung sejak januari hingga juli yakni berjumlah 597 pasien.

Dari hasil analisa situasi didapatkan informasi bahwa didapatkan bahwa faktor pencetus kekambuhan adalah penderita tidak patuh minum obat selama di rumah. Jangka waktu putusnya penderita minum obat bervariasi, dari 3 hari hingga 2 tahun sebelum kekambuhan dan dibawa ke rumah 
sakit jiwa daerah provinsi Jambi. Selain itu, beberapa pernyataan membuktikan bahwa pasien merasa kurang mendapat dukungan dari anggota keluarga yang lain maupun dari lingkungan sekitar. Penderita yang dirawat ulang di rumah sakit jiwa daerah Provinsi Jambi membutuhkan perhatian dari petugas. Perawatan yang berulang kali terkadang menimbulkan kesan bahwa pemberian therapy dan pengobatan selama perawatan tidak berjalan optimal, sehingga ketika pulang ke rumah penderita pasti akan mengalami kekambuhan lagi.

\section{TARGET DAN LUARAN \\ TARGET}

1. Meningkatkan pengetahuan dan wawasan pasien dan keluarga bahwa pentingnya memahami penyebab dan penanganan kekambuhan

2. Pemahaman tentang pencegahan kekambuhan yang sangat penting dilakukan untuk pengobatan yang lebih tuntas dengan memahami faktor-faktor penyebabnya

3. Klien dan keluarga memahami pentingnya untuk minum obat secara teratur dengan dosis yang dianjurk

\section{LUARAN}

Luaran kegiatan ini adalah publikasi pada jurnal ber-ISSN dan publikasi di media social serta peningkatan pengetahuan pada keluarga.

\section{METODE PELAKSANAAN}

Pelaksanaan kegiatan pengabdian dilaksanakan di di Poliklinik Jiwa RS Jiwa Daerah Provinsi Jambi dengan jumlah 28 orang pada bulan Nopember 2019 s/d Januari 2020. Tahap Pelaksanaan meliputi:

$\begin{array}{llr}\text { 1. } & \begin{array}{l}\text { Mengurus surat } \\ \text { masyarakat }\end{array} & \text { pengabdian } \\ \text { 2. } & \begin{array}{l}\text { Mengidentifikasi } \\ \text { keluarga tentang } \\ \text { kekambuhan skizofrenia }\end{array} & \text { penyebahuan } \\ & \end{array}$

\section{Memberikan penyuluhan kesehatan \\ 4. Diskusi dan Tanya jawab \\ 5. Penutup}

\section{HASIL DAN PEMBAHASAN}

Berdasarkan hasil pengabdian masyarakat kepada keluarga di poliklinik jiwa terlihat antusias keluarga selama masa penyuluhan kesehatan. Keluarga cukup memahami tentang materi yang disampaikan oleh penyuluh. Hal ini dapat dilihat dari antusiasme peserta penyuluhan dalam memberikan pertanyaan yang berkaitan dengan topik yang disampaikan penyuluh yakni upaya dalam mencegah kekambuhan pasien gangguan jiwa.

Kambuh merupakan kondisi dimana klien kembali menunjukkan gejala szizofrenia setelah diremisi dari rumah sakit. Penderita mengalami kambuh diikuti perburukan social lebih lanjut pada fungsi dasar klien (Kaplan \&sadock,2006)

Kekambuhan pasien skizofrenia adalah istilah yang secara relatif merefleksikan perburukan gejala atau perilaku yang membahayakan pasien dan atau lingkungannya. Tingkat kekambuhan sering di ukur dengan menilai waktu antara lepas rawat dari perawatan terakhir sampai perawatan berikutnya dan jumlah rawat inap pada periode tertentu (Pratt, 2006).

Secara global angka kekambuhan pada penderita gangguan jiwa mencapai $50 \%-92 \%$ yang disebabkan karena ketidakpatuhan dalam berobat maupun karena kurangnya dukungan dan kondisi kehidupan yang rentan dengan meningkatnya stres (Sheewangisaw, 2012). Klien dengan diagnosa skizofrenia diperkirakan akan kambuh 50\% pada tahun pertama, $70 \%$ pada tahun kedua setelah pulang dari rumah sakit, kekambuhan $100 \%$ pada tahun kelima.

Kekambuhan yang dialami oleh responden dapat terjadi oleh karena berbagai faktor, namun pada intinya tidak terlepas dari factor individu dan lingkungan dimana klien berada. Perawatan di rumah 
ditujukan agar klien yang dinyatakan mengalami perbaikan kondisi dan atau kesembuhan dapat diterima kembali di tengah keluarga dan masyarakat. Sehingga kualitas hidup klien tidak mengalami penurunan setelah didiagnosa dengan skizofrenia. Perawat sebagai ujung tombak pelayanan mempunyai peran strategis dalam membantu klien skizofrenia tidak mengalami kekambuhan. Salah satu dengan memaksimalkan peran perawat sebagai educator bagi klien maupun keluarga.

Menurut Friedman (2010), dukungan keluarga dapat diberikan dalam beberapa bentuk, yaitu : dukungan informasional, emosional, instrumental dan dukungan penilaian. Dukungan informasional yakni keluarga dapat menyediakan informasi dengan menyarankan tentang dokter, terapi yang baik bagi dirinya dan tindakan spesifik bagi individu untuk melawan stresor, dukungan emosional memberikan individu perasaan nyaman, merasa dicintai saat mengalami depresi, bantuan dalam bentuk semangat, empati, rasa percaya, perhatian sehingga individu yang menerimanya merasa berharga. Dukungan instrumental meliputi penyediaan dukungan jasmaniah seperti pelayanan, bantuan finansial dan material berupa bantuan nyata (instrumental support material support), Dukungan penilaian meliputi pertolongan pada individu untuk memahami kejadian depresi dengan baik dan juga sumber depresi dan strategi koping yang dapat digunakan dalam menghadapi stressor.

Peranan keluarga sangat dibutuhkan dalam proses pengobatan pasien dengan gangguan jiwa, kondisi ini yang menyebabkan pentingnya peran keluarga karena keluarga merupakan kelompok kecil yang dapat berinteraksi dengan pasien, secara pribadi keluarga merupakan faktor utama dalam penyembuhan pasien. Keluarga mempunyai fungsi dasar seperti memenuhi kebutuhan fisik, member kasih sayang dan rasa aman

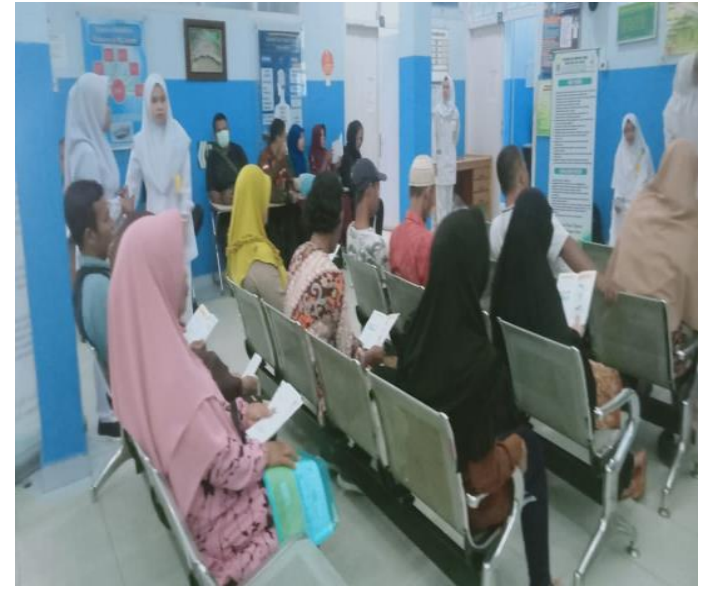

Gambar 1. kegiatan penyuluhan

\section{KESIMPULAN DAN SARAN}

\section{Kesimpulan}

Kegiatan pengabdian masyarakat ini dalam bentuk pemberian pendidikan kesehatan tentang faktor yang pencegah kekambuhan pada pasien telah berjalan lancar dan tanpa hambatan yang bearti. Setelah peserta mengikuti rangkaian acara mulai dari penyampaian materi dan sesi diskusi, peserta memahami tentang faktor pencegah kekambuhan pada pasien gangguan jiwa di Poliklinik Jiwa RS Jiwa Daerah Provinsi Jambi.

\section{Saran}

Diharapkan kegiatan pemberian pendidikan kesehatan dapat lebih ditingkatkan, sehingga setiap pengunjung dan masyarakat memahami tentang faktorfaktor apa saja yang dapat dilakukan untuk mencegah kekambuhan. Selain itu, peran serta aktif masyarakat diharapkan dapat lebih meningkat lagi.

\section{DAFTAR PUSTAKA}

DSM IV. 2012. Diagnosis Gangguan Jiwa Rujukan Ringkas dari PPDGJ-III. Editor oleh Rusdi Salim.Jakarta : FKUI

Friedman. 2010. Keperawatan Keluarga Teori dan Praktek. Jakarta : EGC 
Kaplan \& Sadock. 2007. Buku Ajar Psikiatris Klinis (edisi 2). Jakarta : EGC

Keliat, Budi. 2009. Peran Serta Keluarga dalam Perawatan Klien Gangguan Jiwa. Jakarta : EGC.

Kemenkes RI.(2013). Riset Kesehatan Dasar (Riskesdas) 2013. Jakarta: Badan Penelitian dan Pengembangan Kesehatan

Kunter. 2009. Skizofrenia. Dalam jurnal kesehatan.http//subscrif.com.diakses tanggal 10 Februari 2018.

Profil RS Jiwa Jambi Tahun 2017.

Videbeck, S. 2008. Buku Ajar Keperawatan Jiwa. Jakarta : EGC 